\title{
PENGARUH KETERLIBATAN KERJA, IKLIM ORGANISASI, DAN KEPUASAN KERJA TERHADAP KOMITMEN ORGANISASIONAL
}

\author{
I Gde Raka Ariana ${ }^{1}$ \\ Ni Wayan Mujiati² \\ ${ }^{1,2}$ Fakultas Ekonomi dan Bisnis Universitas Udayana, Bali, Indonesia \\ e-mail: rakaariana70@gmail.com
}

\begin{abstract}
ABSTRAK
Komitmen organisasional merupakan suatu keinginan yang dimiliki oleh anggota organisasi untuk tetap bertahan dalam organisasi dan salah satu faktor penting yang dapat memberikan kontribusi terhadap pencapaian tujuan organisasi. Penelitian ini bertujuan untuk mengetahui pengaruh signifikan dari keterlibatan kerja, iklim organisasi, dan kepuasan kerja terhadap komitmen organisasional karyawan restoran ingka di Kerobokan. Penelitian ini dilakukan pada restoran ingka di Kerobokan. Jenis data yang digunakan adalah data kualitatif yang bersumber dari gambaran umum restoran dan data kuantitatif adalah jumlah karyawan restoran ingka. Jumlah responden sebanyak 45 karyawan. Pengumpulan data menggunakan metode observasi, wawancara dan kuesioner. Teknik analisis data yang digunakan adalah analisis regresi linier berganda. Berdasarkan hasil analisis ditemukan bahwa keterlibatan kerja berpengaruh positif dan signifikan terhadap komitmen organisasional, iklim organisasi berpengaruh positif dan signifikan terhadap komitmen organisasional, dan kepuasan kerja berpengaruh positif dan signifikan terhadap komitmen organisasional.
\end{abstract}

Kata kunci: keterlibatan kerja, iklim organisasi, kepuasan kerja dan komitmen organisasional

\begin{abstract}
Organizational commitment is a desire possessed by members of the organization to remain in the organization and one important factor that can contribute to the achievement of organizational goals. This study aims to determine the significant effect of work involvement, organizational climate, and job satisfaction with organizational commitment of restaurant employees in Kerobokan.This research was conducted on the ingka restaurant in Kerobokan. The type of data used is qualitative data sourced from the restaurant overview and quantitative data is the number of employees of the restaurant ingka. The number of respondents is 45 employees. Data collection using observation methods, interviews and questionnaires. Data analysis technique used is multiple linear regression analysis.Based on the results of the analysis found that the involvement of work has a positive and significant impact on organizational commitment, organizational climate has a positive and significant impact on organizational commitment, and job satisfaction has a positive and significant impact on organizational commitment.
\end{abstract}

Keywords: job engagement, organizational climate, job satisfaction and organizational commitment 


\section{PENDAHULUAN}

Suatu unsur yang penting dalam organisasi adalah sumber daya manusianya. Unsur ini sangat penting dan dibutuhkan dalam suatu organisasi. Sumber daya manusia yang berkualitas pada dasarnya akan dapat membantu organisasi mencapai tujuannya. Apabila tidak ada sumber daya manusia maka tujuan perusahaan tidak akan tercapi dan tidak akan sukses perusahaan tersebut. Peran sumber daya manusia disini adalah mengendalikan elemen-elemen yang ada di perusahaan seperti modal dan teknologi (Indrawan dan Dewi, 2014). Kegagalan mengelola sumber daya manusia dapat mengakibatkan timbulnya gangguan dalam pencapaian tujuan dalam organisasi, baik dalam kinerja, keuntungan, maupun kelangsungan hidup organisasi tersebut (Rayadi, 2012).

Tantangan intensif saat ini banyak dihadapi dalam rangka meningkatkan komitmen organisasi yang berdampak pada keunggulan kompetitif, dan mempertahankan karyawan adalah salah satu kunci dalam meningkatkan komitmen organisasi, (Fatt et al. 2010). Luthans (2006) menyatakan bahwa: "komitmen organisasional sebagai sebuah sikap yang merefleksikan loyalitas karyawan kepada organisasi dan merupakan suatu proses berkelanjutan di mana anggota organisasi mengungkapkan perhatian mereka terhadap organisasi, keberhasilan organisasi serta kemajuan organisasinya". Komitmen organisasi adalah dorongan dari diri sendiri untuk melakukan sesuatu agar dapat mendorong keberhasilan organisasi dengan tetap berpedoman pada tujuan organisasi dan mengutamakan kepentingan organisasi. Suryanatha (2014) menyatakan apabila 
I Gde Raka Ariana, Pengaruh Keterlibatan Kerja...

seorang karyawan kurang bertanggung jawab dalam melaksanakan pekerjaan itu berarti menunjukkan rendahnya komitmen karyawan tersebut dalam organisasi.

Crow et al. (2012) menyatakan bahwa komitmen organisasi adalah keadaan psikologis seorang pegawai yang dapat dilihat dari loyalitas pegawai serta dapat fokus terhadap tujuan yang ditetapkan oleh organisasi. Mohammed dan Anisa (2012) menyatakan bahwa komitmen organisasional merujuk kepada kesiapan karyawan untuk bekerja keras dan mewujudkan tujuan organsiasi, standar organsiasi, prinsip organisasi, etika organisasi dan nilai-nilai organisasi agar tetap berada di organisasi dalam berbagai macam situasi.

Keterlibatan juga berpengaruh terhadap komitmen organiasional. Rahati et al. (2015) menyatakan bahwa keterlibatan kerja merupakan internalisasi yang berkaitan dengan nilai-nilai kebaikan yang berkaitan dengan bagaimana pentingnya bekerja sama antara orang-orang dalam organisasi. Rivai dan Mulyadi (2012:246) menyatakan bahwa keterlibatan kerja adalah derajat sejauh mana seseorang secara psikologis akan memihak pekerjaannya dan menganggap bahwa tingkat kinerjanya penting untuk dirinya.

Penelitian yang dilakukan oleh Mariyanti (2014) menyatakan bahwa dalam komitmen organisasional ini dipengaruhi secara signifikan oleh keterlibatan kerja. Ini berarti tingginya tingkat keterlibatan kerja maka akan tinggi pula komitmen organisasinya. Chin (2012) menyatakan bahwa adanya kontribusi secara signifikan antara keterlibatan kerja terhadap komitmen organisasional. Penelitian lain yang dilakukan oleh Logahan (2014) menyatakan bahwa keterlibatan kerja memiliki pengaruh yang signifikan dan positif terhadap komitmen organisasional. 
Kusumaningtyas (2013) menyatakan bahwa iklim organisasi adalah konsep yang luas untuk diketahui para karyawan organisasi mengenai persepsi tentang sifat atau karakteristik tempat kerja. Susanty (2012) menyatakan bahwa terdapat ketidaksamaan iklim antara organisasi satu dengan lainnya yang memengaruhi perilaku sumber daya manusia yang ada dalam organisasi terbsebut. Iklim organisasi yang baik akan mendatangkan perasaan menyenangkan bagi para pegawainya dan hal ini akan menimbulkan rasa memiliki dan menghargai akan organisasi sehingga pegawai bertekad untuk melakukan sesuatu yang bermanfaat bagi organisasi.

Wirawan (2009) menyatakan iklim organisasi berkaitan dengan persepsi anggota organisasi, mengenai apa yang ada atau terjadi di lingkungan internal organisasi. Semakin tinggi iklim organisasi dalam perusahaan, maka akan semakin tinggi komitmen karyawan. Widiarti (2016) menyatakan bahwa iklim organisasi berpengaruh positif dan signifikan terhadap komitmen organisasional. Hal ini menunjukkan semakin tinggi tingkat iklim organisasi maka semakin tinggi tingkat komitmen organisasional.

Handoko (2014:193) kepuasan kerja merupakan perasaan psikologis yang dirasakan karyawan megenai menyenangkan atau tidaknya pekerjaan yang mereka lakukan. Kepuasan dapat menggambarkan perasaan positif dan negatif karyawan terhadap pekerjaan yang dihadapinya, seperti perasaan untuk berprestasi dan meraih kesuksesan di dalam pekerjaan, mengimplementasikan kepuasan yang tinggi terhadap pegawai yang merasa senang dan nyaman dengan kondisi lingkungan organisasi dan mendapatkan penghargaan dari jeri payahnya (Aziri, 
I Gde Raka Ariana, Pengaruh Keterlibatan Kerja...

2011). Kepuasan kerja dapat mencerminkan apakah karyawan merasa aman terhadap pekerjaannya baik dari segi social ekonomi maupun psikologi (Rivai dan Mulyadi, 2012:246). Kepuasan kerja dapat ditinjau dari dua sisi, yaitu dari sisi karyawan dan sisi perusahaan. Kepuasan kerja dari sisi karyawan terkait dengan perasaan senang karyawan dalam bekerja, sedangkan dari sisi perusahaan merupakan dampak yang ditimbulkan akibat kepuasan kerja karyawan dimana kepuasan kerja ini dalam hal meningkatkan produktivitas serta perilaku karyawan dalam memberikan pelayanan prima (Suwanto dan Priansa, 2011).

Karim dan Rehman (2012) menyatakan bahwa kepuasan kerja dan komitmen organisasional memiliki korelasi yang sangat kuat. Karyawan yang puas cenderung akan lebih setia kepada organisasinya dan mempertahankan sikap positif terhadap pekerjaan mereka. Jonathan et al. (2013) menyatakan bahwa terdapat pengaruh positif kepuasan kerja terhadap komitmen organisasional, dimana apabila mereka puas terhadap pekerjaan mereka maka akan semakin berkomitmen pula karyawan tersebut terhadap organisasi.

Perkembangan zaman yang semakin maju berdampak pada bisnis terutama dalam bidang kuliner (Gonius, 2013) sehingga menjadikan bisnis restoran memiliki prospek yang baik terutama di daerah tujuan wisata khususnya di Provinsi Bali. Restoran Ingka adalah salah satu restoran yang terletak di Jalan Mertanadi no 80, Kerobokan Kelod, Badung, Bali. Restoran Ingka memiliki karyawan dengan jumlah 45 orang yang terbagi dalam masing-masing departemen. 
Tabel 1.

Data Jumlah Karyawan Restoran Ingka 2017

\begin{tabular}{ccc}
\hline No. & Jabatan & Jumlah Karyawan (orang) \\
\hline 1. & Manager & 1 \\
2. & Bartender & 6 \\
3. & Kitchen & 20 \\
4. & Waiter & 14 \\
5. & Security & 4 \\
\hline & & 45 \\
\hline
\end{tabular}

Sumber: Restoran Ingka, 2017

Karyawan yang memiliki komitmen terhadap organisasi akan menjunjung nilai-nilai yang ada di organisasi dan bekerja secara professional agar dapat mengembangkan diri di masa mendatang (Mehdi et al. 2013). Komitmen karyawan sangat penting dalam bisnis restoran karena dalam memberikan kualitas layanan yang baik terhadap konsumen diperlukan sumber daya manusia yang memiliki komitmen tinggi terhadap pekerjaannya. Karyawan yang memiliki komitmen mampu bekerja secara professional sehingga dapat memberikan pelayanan yang baik bagi konsumen dan mampu membantu perusahaan dalam mencapai tujuan organisasi. Restoran sebagai industri yang bergerak dalam bidang pelayanan jasa membutuhkan karyawan yang memiliki komitmen yang tinggi karena segala sesuatu yang diperlukan oleh konsumen harus diberikan pelayanan yang baik.

Pra-survei yang dilakukan di Restoran Ingka dengan melibatkan 20 (dua puluh) responden yang diambil secara acak, ditemukan adanya indikasi yang menunjukkan rendahnya komitmen organisasional. Indikasi tersebut seperti karyawan mengatakan memiliki pemikiran untuk keluar karena tidak yakin akan tetap bertahan di restoran. Fenomena tersebut terjadi akibat pihak restoran kurang memperhatikan kebutuhan karyawan sehingga karyawan merasa kurang puas 
I Gde Raka Ariana, Pengaruh Keterlibatan Kerja...

bekerja di restoran. Penurunan komitmen karyawan di Restoran Ingka ditandai dengan tingkat absensi yang masih tinggi. Penelitian yang dilakukan oleh Crow et al. (2012) menyatakan bahwa rendahnya komitmen organisasional dapat disebabkan dengan perilaku negatif seperti keinginan berpindah kerja, penyimpangan kerja, dan absensi. Permasalahan tersebut menunjukkan masih kurangnya komitmen karyawan terhadap organisasi di Restoran Ingka. Berikut tingkat absensi karyawan di Restoran Ingka dapat dilihat pada Tabel 2. di bawah ini.

Tabel 2.

\begin{tabular}{|c|c|c|c|c|c|c|c|}
\hline \multicolumn{8}{|c|}{$\begin{array}{l}\text { Data Tingkat Absensi Karyawan Restoran Ingka September - November } \\
\qquad 2017\end{array}$} \\
\hline Bulan & Tahun & $\begin{array}{c}\text { Total } \\
\text { Karya } \\
\text { wan }\end{array}$ & $\begin{array}{c}\text { Total } \\
\text { Hari } \\
\text { Kerja }\end{array}$ & $\begin{array}{c}\text { Total } \\
\text { Kehadira } \\
n \\
\text { Karyawa } \\
\text { n } \\
\text { Seharusn } \\
\text { ya (hari) }\end{array}$ & $\begin{array}{c}\text { Absensi } \\
\text { Karyawa } \\
\text { n (hari) }\end{array}$ & $\begin{array}{c}\text { Total } \\
\text { Kehadira } \\
\text { n (hari) }\end{array}$ & $\begin{array}{c}\text { Persentase } \\
\text { Ketidakhadira } \\
\text { n Karyawan } \\
(\%)\end{array}$ \\
\hline September & 2017 & 46 & 30 & 1380 & 52 & 1328 & 3,8 \\
\hline Oktober & 2017 & 45 & 31 & 1395 & 60 & 1335 & 4,3 \\
\hline November & 2017 & 45 & 30 & 1350 & 53 & 1297 & 3,9 \\
\hline Total & & 136 & 91 & 4125 & 165 & 3960 & 12,0 \\
\hline Rata-rat & & 45 & 30 & 1375 & 55 & 1320 & 4,0 \\
\hline
\end{tabular}

Sumber: Restoran Ingka, 2017

Perhitungan tingkat absensi karyawan Restoran Ingka menunjukkan bahwa tingkat absensi karyawan 4 persen. Ardana dkk. (2012:52) menyatakan rata rata absensi 2-3 persen perbulan masih bisa dinyatakan baik dan absensi lebih dari 3 persen menggambarkan kondisi yang tidak baik dalam organisasi. Data absensi karyawan Restoran Ingka menunjukkan tingkat absensi lebih dari 3 persen dan ini menunjukkan adanya indikasi masalah yang terjadi di restoran tersebut khususnya komitmen karyawan. Safitri dkk. (2014) menyatakan tingkat komitmen organisasi 
yang tinggi dari para karyawannya wajib dimiliki oleh organisasi apabila ingin mencapai tujuannya. Berdasarkan uraian diatas dapat diketahui bahwa komitmen organisasional di Restoran Ingka masih belum optimal. Berdasarkan uraian diatas maka peneliti menarik mengambil judul Pengaruh Keterlibatan Kerja, Iklim Organisas dan Kepuasan Kerja Terhadap Komitmen Organisasional di Restoran Ingka.

Berdasarkan latar belakang masalah yang telah diuraikan diatas, maka pokok permasalahan pada penelitian ini adalah apakah keterlibatan kerja, iklim organisasi, dan kepuasan kerja berpengaruh terhadap komitmen organisasional? Dari rumusan masalah tersebut, maka tujuan penelitian ini adalah untuk menjelaskan pengaruh keterlibatan kerja, iklim organisasi, dan kepuasan kerja terhadap komitmen organisasional.

Penelitian ini memberikan kegunaan teoritis dengan harapan hasil penelitian dapat memperluas wawasan dan pengetahuan serta bukti empiris mengenai pengaruh keterlibatan kerja, iklim oganisasi, dan kepuasan kerja terhadap komitmen organisasional di Restoran Ingka. Penelitian ini juga memberikan kegunaan praktis dengan harapan hasil penelitian dapat dijadikan sebagai bahan pertimbangan dan masukan terhadap objek penelitian, berkaitan dengan pengaruh keterlibatan kerja, iklim organisasi, dan kepuasan kerja terhadap komitmen organisasional di Restoran Ingka. 
I Gde Raka Ariana, Pengaruh Keterlibatan Kerja...

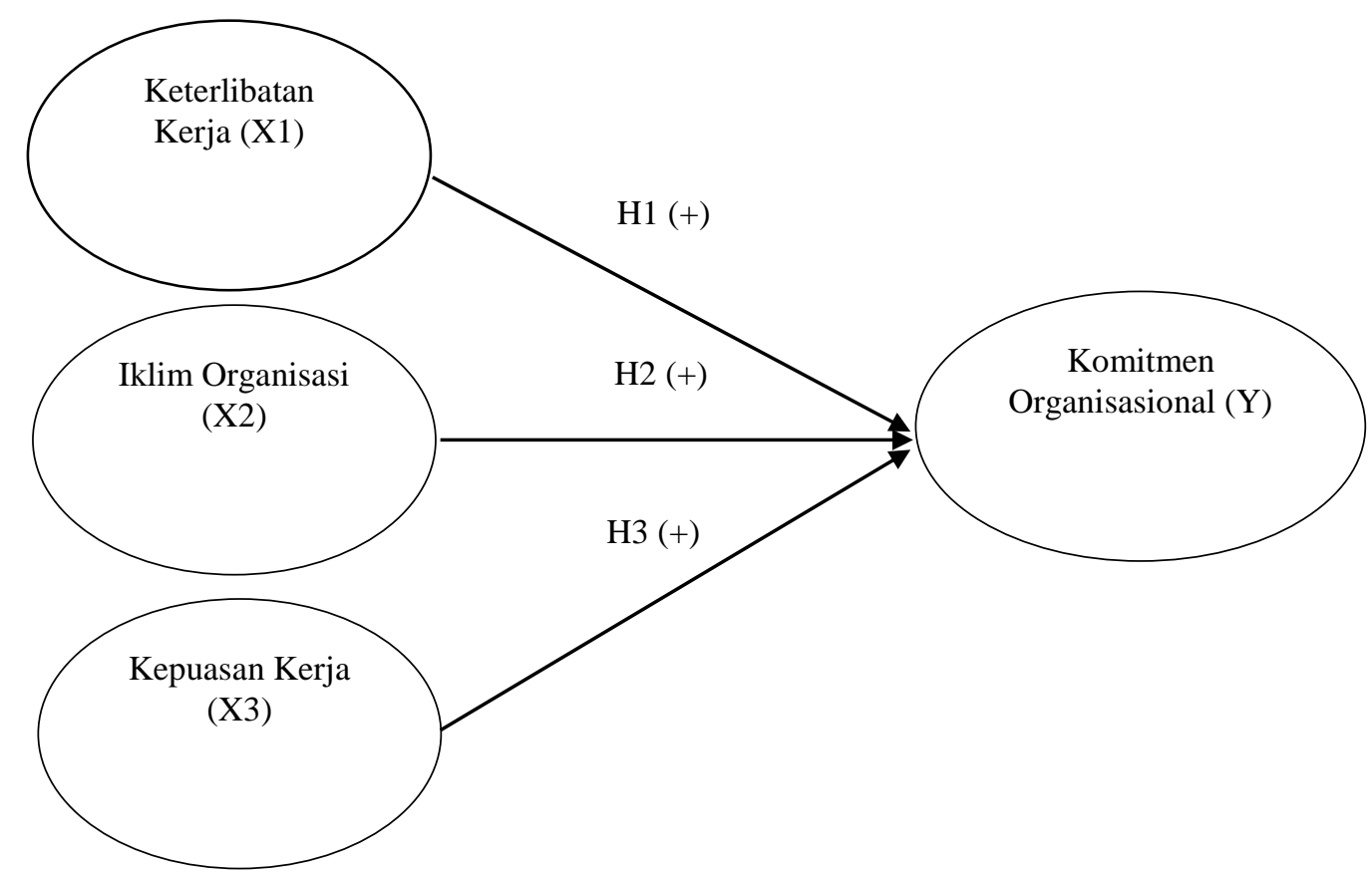

Gambar 1. Kerangka Konseptual

Luthans (2006) menyatakan bahwa komitmen organisasional sebagai refleksi loyalitas karyawan kepada organisasi serta pengungkapan perhatian terhadap organisasi bagaimana kemajuan dan keberhasilan yang dicapai perusahaan. Suma dan Lesha (2013) menyatakan bahwa komitmen organisasi dianggap sebagai kekuatan dari identifikasi individu dengan keterlibatannya dengan organisasi. Dimana terdapat tiga factor yang menandai kekuatan relative ini yaitu keyakinan yang kuat dan penerimaan atas tujuan dan nilai-nilai organisasi, kesediaan untuk mengerahkan usaha atas nama organisasi dan memiliki keinginan yang kuat untuk mempertahankan keanggotaan dalam organisasi.

Penelitian yang dilakukan oleh Mariyanti (2014) menyatakan bahwa keterlibatan kerja merupakan salah satu factor yang berpengaruh terhadap 
komitmen organisasional. Semakin tinggi tingkat keterlibatan kerja maka semakin tinggi pula komitmen organisasinya. Chin (2012) menyatakan bahwa adanya terdapat kontribusi keterlibatan kerja terhadap komitmen organisasional. Penelitian yang dilakukan oleh Ansel dan Wijono (2012), Logahan (2014), serta Liwun dan Prabowo (2015) menyatakan bahwa keterlibatan kerja berpengaruh positif terhadap komitmen organisasional. Hipotesis yang dapat diajukan dalam penelitian ini, berdasarkan hasil penelitian sebelumnya adalah sebagai berikut.

$\mathrm{H}_{1}$ : Keterlibatan kerja berpengaruh positif dan signifikan terhadap komiten organisasi.

Wirawan (2009) menyatakan bahwa iklim organisasi berkaitan erat dengan proses penciptaan lingkungan kerja yang kondusif yang akan menimbulkan hubungan harmonis antar elemen organisasi. Semakin tinggi iklim organisasi dalam perusahaan, maka akan semakin tinggi komitmen karyawan. Penelitian yang dilakukan oleh Affandi (2002), Safiri dan Putra (2015), Adiapsari (2012), Suarningsih dkk. (2013), serta Widiarti dan Dewi (2016) juga menyatakan bahwa iklim organisasi berpengaruh positif terhadap komitmen organisasional. Hipotesis yang dapat diajukan dalam penelitian ini, berdasarkan hasil penelitian sebelumnya adalah sebagai berikut.

$\mathrm{H}_{2}$ : Iklim organisasi berpengaruh positif dan signifikan terhadap komitmen organisasi.

Jonathan et al. (2013) menyatakan bahwa terdapat pengaruh positif kepuasan kerja terhadap komitmen organisasional, jadi apabila karyawan puas akan pekerjaannya maka karyawan akan semakin berkomitmen terhadap organisasi. Oyewobi et al. (2012) pada penelitiannya quantity surveyor dalam 
pelayanan publik Nigeria menyatakan bahwa memang terdapat korelasi positif antara variabel kepuasan kerja dengan komitmen kerja. Hasil penelitian dari Sutanto dan Tania (2013), Srivastava (2013), serta Devi dan Adnyani (2015) menyatakan bahwa kepuasan kerja berpengaruh positif dan signifikan terhadap komitmen organisasional. Hipotesis yang dapat diajukan dalam penelitian ini, berdasarkan hasil penelitian sebelumnya adalah sebagai berikut.

$\mathrm{H}_{3}$ : Kepuasan kerja berpengaruh positif dan signifikan terhadap komitmen organsasi.

\section{METODE PENELITIAN}

Desain penelitian ini menggunakan pendekatan kuantitatif yang bersifat asosiatif yang bertujuan untuk mengetahui pengaruh antar dua valiabel atau lebih. Lokasi penelitian ini dilakukan pada restoran ingka di Kerobokan. Objek penelitian yang digunakan dalam penelitian ini yaitu keterlibatan kerja, iklim organisasi, kepuasan kerja, dan komitmen organisasional. Identifikasi variabel dalam penelitian ini terdapat dua jenis variabel yang dikaji, yaitu variabel dependen (Y) yang digunakan dalam penelitian ini adalah komitmen organisasional (Y) dan variabel independen penelitian ini adalah keterlibatan kerja (X1), iklim organisasi (X2), dan kepuasan kerja (X3).

Populasi pada penelitian ini adalah seluruh karyawan restoran ingka di Kerobokan yang berjumlah 45 orang. Metode yang digunakan dalam penentuan sampel pada penelitian ini adalah metode sampling jenuh. Jenis data yang digunakan dalam penelitian ini adalah data kualitatif dan kuantitatif. Sumber data yang digunakan dalam penelitian ini adalah sumber data primer yang diperoleh 
langsung dari lapangan dan sumber data sekunder yang diperoleh dari media perantara atau dokumen. Metode pengumpulan data dengan menggunakan metode observasi, wawancara, dan kuisioner.

Uji validitas instrumen dapat digunakan untuk mengukur apa yang seharusnya diukur dan digunakan untuk mengukur sejauh mana ketepatan pertanyaan yang digunakan dalam kuisioner untuk mengukur variabel yang akan diteliti (Sugiyono, 2014:172). Uji reliabilitas instrumen digunakan untuk mencari sejauh mana alat ukur yang digunakan itu konsisten dan tidak memberikan hasil yang berubah-ubah. Instrumen dikatakan reliabel apabila instrument tersebut telah digunakan untuk mengukur data beberapa kali tetapi tetap menghasilkan data yang konsisten (Sugiyono, 2014:172).

Teknik analisis data yang digunakan pada penelitian ini adalah model regresi linier berganda. Metode regresi linier berganda digunakan dalam penelitian ini untuk mengetahui pengaruh Keterlibatan Kerja ( $\left.\mathrm{X}_{1}\right)$, Iklim Organisasi $\left(\mathrm{X}_{2}\right)$, Kepuasan Kerja $\left(\mathrm{X}_{3}\right)$ dan Komitmen Organisasional (Y). Teknik pengujian data menggunakan uji asumsi klasik yang berfungsi untuk menilai persyaratan-persyaratan yang harus dipenuhi oleh suatu data agarmendapatkan hasil yang valid.

\section{HASIL DAN PEMBAHASAN}

\section{Karakteristik Responden}

Karakteristik responden merupakan gambaran bagaimana profil responden yang digunakan dalam penelitian. Data hasil penelitian yang dilakukan terhadap karyawan Restoran Ingka, maka dapat diketahui gambaran profil yang meliputi 
I Gde Raka Ariana, Pengaruh Keterlibatan Kerja...

empat aspek, yaitu: jenis kelamin, usia, dan pendidikan terakhir. Jumlah responden yang digunakan dalam penelitian ini sebanyak 45 responden.

Jenis kelamin responden secara rinci dapat dijelaskan pada Tabel 3.

Tabel 3.

Karakteristik Responden Berdasarkan Jenis Kelamin

\begin{tabular}{ccc}
\hline Jenis Kelamin & N & Jumlah Persentase (\%) \\
\hline Laki-Laki & 31 & 68,9 \\
Perempuan & 14 & 31,1 \\
\hline Jumlah & $\mathbf{4 5}$ & $\mathbf{1 0 0}$
\end{tabular}

Sumber: Data diolah, 2018

Tabel 3 menunjukkan bahwa karyawan dengan jenis kelamin laki-laki berjumlah 31 orang atau sebesar 68,9 persen, sedangkan karyawan dengan jenis kelamin perempuan berjumlah 14 orang atau sebesar 31,1 persen. Data ini menunjukkan bahwa jumlah karyawan laki-laki lebih banyak dibandingkan dengan perempuan. Hal ini dikarenakan alasan keamanan karena jam kerja yang sampai larut malam.

Usia responden secara rinci dapat dijelaskan pada Tabel 4.

Tabel 4.

Karakteristik Responden Berdasarkan Usia

\begin{tabular}{lcc}
\hline \multicolumn{1}{c}{ Usia } & N & Jumlah Persentase (\%) \\
\hline 18-30 tahun & 32 & 71,1 \\
$31-40$ tahun & 9 & 20 \\
41-50 tahun & 4 & 8,9 \\
\hline Jumlah & $\mathbf{4 5}$ & $\mathbf{1 0 0}$
\end{tabular}

Tabel 4 menunjukkan bahwa karyawan Restoran Ingka sebagian besar berumur 18-30 tahun dengan jumlah sebanyak 32 orang atau berkisar 71,1 persen. Karyawan restoran didominasi oleh usia 18-30 tahun karena usia tersebut merupakan usia produktif.

Pendidikan terakhir responden secara rinci dijelaskan pada Tabel 5. 
Tabel 5.

Karakteristik Responden Berdasarkan Pendidikan Terakhir

\begin{tabular}{lcc}
\hline \multicolumn{1}{c}{ Pendidikan Terakhir } & N & Jumlah Persentase (\%) \\
\hline SMP & 2 & 4,4 \\
SMA/SMK & 24 & 53,3 \\
Diploma & 16 & 35,6 \\
Sarjana & 3 & 6,7 \\
\hline Jumlah & $\mathbf{4 5}$ & $\mathbf{1 0 0}$
\end{tabular}

Tabel 5 menunjukkan jumlah tertinggi terletak pada tingkat pendidikan terakhir SMA/SMK sebanyak 24 orang dengan persentase 53,3 persen. Karyawan dengan pendidikandiploma sebanyak 16 orang dengan persentase 35,6 persen dan yang paling rendah karyawan dengan tingkat pendidikan SMP sebanyak 2 orang dengan persentase 4,4 persen. Faktor tingkat pendidikan merupakan salah satu penentu kualitas sumber daya manusia.

\section{Uji Reliabilitas}

Hasil uji reliabilitas instrumen pada penelitian ini disajikan pada Tabel 6.

Tabel 6.

Hasil Uji Reliabilitas

\begin{tabular}{ccc}
\hline Variabel & Cronbach's Alpha & Keterangan \\
\hline Keterlibatan Kerja & 0,667 & Reliabel \\
Iklim Organisasi & 0,796 & Reliabel \\
Kepuasan Kerja & 0,815 & Reliabel \\
Komitmen Organisasional & 0,689 & Reliabel \\
\hline
\end{tabular}

Sumber: Data diolah, 2018

Tabel 6 menunjukkan bahwa masing-masing nilai Cronbach's Alpha pada tiap instrumen penelitian lebih besar dari 0,6 (Cronbach's Alpha >0,6). Dengan demikian hasil tersebut menunjukkan bahwa semua instrument terbukti reliabel, sehingga dapat digunakan untuk melakukan penelitian.

\section{Uji Validitas}

Hasil uji validitas instrumen penelitian disajikan pada Tabel 7. 
Tabel 7.

Hasil Uji Validitas

\begin{tabular}{cccc}
\hline Variabel & Instrumen & Pearson Correlation & Keterangan \\
\hline \multirow{3}{*}{ Keterlibatan Kerja } & X1.1 & 0,756 & Valid \\
(X1) & X1.2 & 0,727 & Valid \\
& X1.3 & 0,663 & Valid \\
& X1.4 & 0,459 & Valid \\
\hline \multirow{4}{*}{ Iklim Organisasi } & X2.1 & 0,752 & Valid \\
(X2) & X2.2 & 0,862 & Valid \\
& X2.4 & 0,860 & Valid \\
& X2.5 & 0,560 & Valid \\
Kepuasan Kerja & X3.1 & 0,673 & Valid \\
(X3) & X3.2 & 0,729 & Valid \\
& X3.3 & 0,798 & Valid \\
& X3.4 & 0,751 & Valid \\
& X3.5 & 0,701 & Valid \\
Komitmen Organisasional & Y.1 & 0,814 & Valid \\
\hline (Y) & Y.2 & 0,618 & Valid \\
& Y.3 & 0,492 & Valid \\
& Y.4 & 0,544 & Valid \\
& Y.5 & 0,520 & Valid \\
& Y.6 & 0,658 & Valid \\
& Y.7 & 0,536 & Valid \\
& Y.8 & 0,563 & Valid \\
& & 0,575 & Valid
\end{tabular}

Sumber: Data diolah, 2018

Tabel 7. menunjukkan bahwa seluruh koefisien korelasi dari indikator variabel penelitian yang diuji nilainya lebih besar dari 0,30 ( $\mathrm{r}>0,3)$. Dengan demikian hasil tersebut menunjukkan bahwa seluruh indikator penelitian terbukti valid.

\section{Deskripsi Variabel Penelitian}

Table 8. memperlihatkan variabel dari komitmen organisasional dapat diuji dengan mempergunakan 8 item pertanyaan yang bersangkutan dengan komitmen organisasional yang disarankan oleh karyawan di restoran. 
Tabel 8.

Deskripsi Jawaban Responden terhadap Komitmen Organisasional

\begin{tabular}{|c|c|c|c|c|c|c|c|c|c|}
\hline \multirow{2}{*}{ No } & \multirow{2}{*}{ Indikator } & \multicolumn{5}{|c|}{ Skor Jawaban } & \multirow{2}{*}{$\begin{array}{l}\text { Jumlah } \\
\text { Skor }\end{array}$} & \multirow{2}{*}{$\begin{array}{l}\text { Rata- } \\
\text { Rata }\end{array}$} & \multirow{2}{*}{ Ket } \\
\hline & & 1 & 2 & 3 & 4 & 5 & & & \\
\hline 1 & $\begin{array}{l}\text { Merasa terikat secara emosional } \\
\text { dengan perusahaan. }\end{array}$ & 0 & 3 & 11 & 12 & 19 & 182 & 4,04 & Baik \\
\hline 2 & $\begin{array}{l}\text { Memiliki rasa kekeluargaan dalam } \\
\text { perusahaan. }\end{array}$ & 0 & 6 & 10 & 15 & 14 & 172 & 3,82 & Baik \\
\hline 3 & Merasa ikut memiliki perusahaan. & 0 & 3 & 15 & 11 & 16 & 175 & 3,88 & Baik \\
\hline 4 & $\begin{array}{l}\text { Mengalami kerugian apabila } \\
\text { meninggalkan perusahaan. }\end{array}$ & 0 & 7 & 13 & 11 & 14 & 167 & 3,71 & Baik \\
\hline 5 & $\begin{array}{l}\text { Memiliki sedikit pilihan jika } \\
\text { meninggalkan perusahaan. }\end{array}$ & 0 & 3 & 12 & 14 & 16 & 178 & 3,95 & Baik \\
\hline 6 & $\begin{array}{l}\text { Terdapat konsekuensi yang tidak } \\
\text { dapat saya tanggung apabila } \\
\text { meninggalkan perusahaan. }\end{array}$ & 0 & 4 & 7 & 15 & 19 & 184 & 4,08 & Baik \\
\hline 7 & $\begin{array}{l}\text { Tetap tinggal diperusahaan karena } \\
\text { komitmen saya terhadap perusahaan. }\end{array}$ & 0 & 5 & 14 & 14 & 12 & 168 & 3,73 & Baik \\
\hline 8 & Tetap loyal terhadap perusahaan. & 0 & 7 & 8 & 11 & 19 & 177 & 3,93 & Baik \\
\hline & Rata-Rata & & & & & & & 3,89 & \\
\hline
\end{tabular}

Tabel 8 menunjukkan bahwa rata-rata skor dari 8 pernyataan mengenai komitmen organisasional yaitu sebesar 3,89 yang berada dikisaran 3,41 - 4,20 yang berarti baik. Hal ini berarti bahwa komitmen organisasional di Restoran Ingka berjalan baik. Distribusi jawaban responden terhadap komitmen organisasional nilai rata-rata tertingginya sebesar 4,08 pada pernyataan saya merasa terdapat konsekuensi yang tidak dapat saya tanggung jika meninggalkan perusahaan dan untuk nilai rata-rata terendah sebesar 3,71 pada pernyataan saya merasa mengalami kerugian apabila meninggalkan perusahaan.

Table 9 memperlihatkan variabel dari keterlibatan kerja dapat diuji dengan mempergunakan 4 item pertanyaan yang bersangkutan dengan keterlibatan kerja yang disarankan oleh karyawan di restoran. 
Tabel 9.

Deskripsi Jawaban Responden terhadap Keterlibatan Kerja

\begin{tabular}{|c|c|c|c|c|c|c|c|c|c|}
\hline \multirow{2}{*}{ No } & \multirow{2}{*}{ Indikator } & \multicolumn{5}{|c|}{ Skor Jawaban } & \multirow{2}{*}{$\begin{array}{l}\text { Jumlah } \\
\text { Skor }\end{array}$} & \multirow{2}{*}{$\begin{array}{l}\text { Rata- } \\
\text { Rata }\end{array}$} & \multirow{2}{*}{ Ket } \\
\hline & & 1 & 2 & 3 & 4 & 5 & & & \\
\hline 1 & $\begin{array}{l}\text { Respon yang diberikan terhadap } \\
\text { suatu pekerjaan sesuai dengan apa } \\
\text { yang diharapkan. }\end{array}$ & 0 & 4 & 9 & 14 & 18 & 181 & 4,02 & Baik \\
\hline 2 & $\begin{array}{l}\text { Terlibat langsung dalam setiap } \\
\text { pekerjaan yang telah ditugaskan. }\end{array}$ & 0 & 2 & 12 & 19 & 12 & 185 & 4,11 & Baik \\
\hline 3 & $\begin{array}{l}\text { Berprinsip bahwa semua pekerjaan } \\
\text { yang dilimpahkan harus } \\
\text { diselesaikan sesuai target pekerjaan } \\
\text { itu sendiri. }\end{array}$ & 0 & 5 & 11 & 12 & 17 & 176 & 3,91 & Baik \\
\hline 4 & $\begin{array}{l}\text { Merasa tidak tenang apabila } \\
\text { pekerjaan belum terselesaikan }\end{array}$ & 0 & 4 & 8 & 14 & 19 & 215 & 4,77 & $\begin{array}{l}\text { Sangat } \\
\text { baik }\end{array}$ \\
\hline & Rata-Rata & & & & & & & 4,20 & \\
\hline
\end{tabular}

Sumber: Data diolah, 2018

Tabel 9 menunjukkan bahwa rata-rata skor dari 4 pernyataan mengenai keterlibatan kerja yaitu sebesar 4,20 yang berada dikisaran 3,41 - 4,20 yang berarti baik. Hal ini berarti bahwa keterlibatan kerja di Restoran Ingka berjalan baik. Distribusi jawaban responden terhadap keterlibatan kerja nilai rata-rata tertingginya sebesar 4,77 pada pernyataan saya merasa tidak senang apabila pekerjaan belum terselesaikan dan untuk nilai rata-rata terendah sebesar 3,91 pada pernyataan saya berprinsip bahwa semua pekerjaan yang dilimpahkan harus diselesaikan sesuai target.

Table 10 memperlihatkan variabel dari iklim organisasi dapat diuji dengan mempergunakan 5 item pertanyaan yang bersangkutan dengan iklim organisasi yang disarankan oleh karyawan di restoran.

Tabel 10. menunjukkan bahwa rata-rata skor dari 5 pernyataan mengenai iklim organisasi yaitu sebesar 4,33 yang berada dikisaran 3,41-4,20 yang berarti baik. Hal ini berarti bahwa iklim organisasi di Restoran Ingka berjalan baik. Distribusi jawaban responden terhadap iklim organisasi nilai rata-rata tertingginya sebesar 4,64 pada pernyataan saya mendapatkan dukungan yang diberikan oleh 
atasan maupun rekan kerja dan untuk nilai rata-rata terendah sebesar 4,04 pada pernyataan saya mendapat penghargaan saat dapat menyelesaikan tugas dengan baik.

Tabel 10.

Deskripsi Jawaban Responden terhadap Iklim Organisasi

\begin{tabular}{|c|c|c|c|c|c|c|c|c|c|}
\hline \multirow{2}{*}{ No } & \multirow{2}{*}{ Indikator } & \multicolumn{5}{|c|}{ Skor Jawaban } & \multirow{2}{*}{$\begin{array}{c}\text { Jumlah } \\
\text { Skor }\end{array}$} & \multirow{2}{*}{$\begin{array}{l}\text { Rata- } \\
\text { Rata }\end{array}$} & \multirow{2}{*}{ Ket } \\
\hline & & 1 & 2 & 3 & 4 & 5 & & & \\
\hline 1 & $\begin{array}{l}\text { Semua karyawan sudah } \\
\text { mendapatkan pembagian pekerjaan } \\
\text { yang jelas. }\end{array}$ & 0 & 0 & 2 & 27 & 16 & 194 & 4,31 & $\begin{array}{c}\text { Sangat } \\
\text { baik }\end{array}$ \\
\hline 2 & $\begin{array}{l}\text { Memiliki tanggung jawab dalam } \\
\text { mengambil keputusan terhadap } \\
\text { tugas yang diberikan. }\end{array}$ & 0 & 0 & 6 & 27 & 12 & 186 & 4,13 & Baik \\
\hline 3 & $\begin{array}{l}\text { Mendapat penghargaan saat dapat } \\
\text { menyelesaikan tugas dengan baik. }\end{array}$ & 0 & 0 & 8 & 27 & 10 & 182 & 4,04 & Baik \\
\hline 4 & $\begin{array}{l}\text { Mendapat dukungan yang diberikan } \\
\text { oleh atasan maupun rekan kerja. }\end{array}$ & 0 & 0 & 0 & 16 & 29 & 209 & 4,64 & $\begin{array}{c}\text { Sangat } \\
\text { baik }\end{array}$ \\
\hline 5 & $\begin{array}{l}\text { Senang dengan komitmen yang } \\
\text { telah ada sehingga dapat mencapai } \\
\text { tujuan perusahaan bersama-sama. }\end{array}$ & 0 & 0 & 9 & 22 & 14 & 185 & 4,11 & Baik \\
\hline & Rata-Rata & & & & & & & 4,33 & \\
\hline
\end{tabular}

Sumber: Data diolah, 2018

Table 11 memperlihatkan variabel dari kepuasan kerja dapat diuji dengan mempergunakan 5 item pertanyaan yang bersangkutan dengan kepuasan kerja yang disarankan oleh karyawan di restoran.

Tabel 11 menunjukkan bahwa rata-rata skor dari 5 pernyataan mengenai iklim organisasi yaitu sebesar 3,96 yang berada dikisaran 3,41 - 4,20 yang berarti baik. Hal ini berarti bahwa kepuasan kerja di Restoran Ingka berjalan baik. Distribusi jawaban responden terhadap kepuasan kerja nilai rata-rata tertingginya sebesar 4,20 pada pernyataan saya puas dengan gaji yang saya terima sesuai dengan tanggung jawab pekerjaan dan untuk nilai rata-rata terendah sebesar 3,91 ada tiga pernyataan yaitu saya puas dengan adanya dukungan dari atasan, saya puas dengan adanya kesempatan promosi, dan saya puas dengan hubungan baik antara rekan kerja. 
Tabel 11.

Deskripsi Jawaban Responden terhadap Kepuasan Kerja

\begin{tabular}{|c|c|c|c|c|c|c|c|c|c|}
\hline \multirow{2}{*}{ No } & \multirow{2}{*}{ Indikator } & \multicolumn{5}{|c|}{ Skor Jawaban } & \multirow{2}{*}{$\begin{array}{l}\text { Jumlah } \\
\text { Skor }\end{array}$} & \multirow{2}{*}{$\begin{array}{l}\text { Rata- } \\
\text { Rata }\end{array}$} & \multirow{2}{*}{ Ket. } \\
\hline & & 1 & 2 & 3 & 4 & 5 & & & \\
\hline 1 & $\begin{array}{l}\text { Puas dengan pekerjaan yang } \\
\text { diberikan. }\end{array}$ & 0 & 8 & 6 & 15 & 16 & 174 & 3,86 & Baik \\
\hline 2 & $\begin{array}{l}\text { Puas dengan gaji yang saya terima } \\
\text { sesuai dengan tanggung jawab } \\
\text { pekerjaan. }\end{array}$ & 0 & 11 & 11 & 14 & 9 & 189 & 4,20 & Baik \\
\hline 3 & $\begin{array}{l}\text { Puas dengan adanya dukungan dari } \\
\text { atasan. }\end{array}$ & 0 & 3 & 12 & 16 & 14 & 176 & 3,91 & Baik \\
\hline 4 & $\begin{array}{l}\text { Puas dengan adanya kesempatan } \\
\text { promosi. }\end{array}$ & 0 & 3 & 13 & 14 & 15 & 176 & 3,91 & Baik \\
\hline 5 & $\begin{array}{l}\text { Puas dengan hubungan yang baik } \\
\text { antara rekan kerja. }\end{array}$ & 0 & 6 & 8 & 15 & 16 & 176 & 3,91 & Baik \\
\hline & Rata-Rata & & & & & & & 3,96 & \\
\hline
\end{tabular}

Sumber: Data diolah, 2018

\section{Hasil Regresi Linier Berganda}

Hasil analisis regresi linier berganda seperti pada tabel 12.

Tabel 12.

Hasil Analisis Regresi Linier Berganda

\begin{tabular}{|c|c|c|c|c|c|}
\hline \multirow[t]{2}{*}{ Model } & \multicolumn{2}{|c|}{$\begin{array}{c}\text { Unstandardized } \\
\text { Coefficients }\end{array}$} & \multirow{2}{*}{$\begin{array}{l}\text { Standardizd } \\
\text { Coefficients }\end{array}$} & \multirow[t]{2}{*}{$\mathbf{t}$} & \multirow[t]{2}{*}{ Sig. } \\
\hline & B & Std. Error & & & \\
\hline$($ Constant $)$ & 8,985 & 7,182 & & 1,251 & 0,218 \\
\hline Keterlibatan Kerja & 0,561 & 0,213 & 0,308 & 2,634 & 0,010 \\
\hline Iklim Organisasi & 0,336 & 0,154 & 0,207 & 2,186 & 0,032 \\
\hline Kepuasan Kerja & 0,480 & 0,171 & 0,327 & 2,802 & 0,007 \\
\hline R Square & & & & & \\
\hline F Hitung $\quad=13,409$ & & & & & \\
\hline Signifikansi $F=0,000$ & & & & & \\
\hline
\end{tabular}

Persamaan regresi pada Tabel 12. dapat disusun sebagai berikut:

$$
\mathrm{Y}=8,985+0,561 \mathrm{X}_{1}+0,336 \mathrm{X}_{2}+0,480 \mathrm{X}_{3}+\mathrm{e}
$$

Persamaan diatas dapat dijelaskan sebagai berikut: (1) $\beta_{1}=0,561$ berarti pengaruh keterlibatan kerja $\left(\mathrm{X}_{1}\right)$ mengakibatkan peningkatan komitmen organisasional (Y) karyawan, dengan asumsi variabel bebas yang lain dianggap konstan. (2) $\beta_{2}=0,336$ berarti pengaruh iklim organisasi $\left(X_{2}\right)$ mengakibatkan peningkatan komitmen organisasional (Y) karyawan, dengan asumsi variabel 
bebas yang lain dianggap konstan. (3) $\beta_{3}=0,480$ berarti pengaruh kepuasan kerja $\left(\mathrm{X}_{3}\right)$ mengakibatkan peningkatan komitmen organisasional $(\mathrm{Y})$ karyawan, dengan asumsi variabel bebas yang lain dianggap konstan.

\section{Hasil Uji Asumsi Klasik}

Tabel 13.

Hasil Uji Normalitas

\begin{tabular}{cc}
\hline & Unstandardized Residual \\
\hline $\mathrm{N}$ & 45 \\
Kolmogorov-Smirnov $Z$ & 0,683 \\
Asymp. Sig. (2-tailed) & 0,740 \\
\hline
\end{tabular}

Sumber: Data diolah, 2018

Tabel 13. menunjukkan bahwa nilai Kolmogorov-Smirnov Z sebesar 0,683, sedangkan nilai Asymp. Sig. (2-tailed) sebesar 0,740. Hal ini menunjukkan bahwa model persamaan regresi tersebut telah berdistribusi normal karena nilai signifikansinya lebih besar dari nilai alpha 0,05 .

Tabel 14.

Hasil Uji Heteroskedastisitas

\begin{tabular}{|c|c|c|c|c|c|}
\hline \multirow[t]{2}{*}{ Model } & \multicolumn{2}{|c|}{$\begin{array}{c}\text { Unstandardized } \\
\text { Coefficients }\end{array}$} & \multirow{2}{*}{$\begin{array}{l}\text { Standardizd } \\
\text { Coefficients }\end{array}$} & \multirow[t]{2}{*}{$\mathbf{t}$} & \multirow[t]{2}{*}{ Sig. } \\
\hline & $\mathrm{B}$ & Std. Error & & & \\
\hline (Constant $)$ & 7,509 & 4,342 & & 1,729 & 0,091 \\
\hline Keterlibatan Kerja & 0,305 & 0,202 & 0,274 & 1,508 & 0,139 \\
\hline Iklim Organisasi & $-0,289$ & 0,158 & $-0,271$ & $-1,826$ & 0,075 \\
\hline Kepuasan Kerja & $-0,178$ & 0,114 & $-0,286$ & $-1,536$ & 0,126 \\
\hline
\end{tabular}

Sumber: Data diolah, 2018

Tabel 14. menunjukkan bahwa nilai Sig. dari variabel keterlibatan kerja sebesar 0,139, iklim organisasi sebesar 0,075 dan kepuasan kerja sebesar 0,126. Nilai tersebut lebih besar dari 0,05 yang berarti tidak terdapat pengaruh antara variabel bebas terhadap absolute residual sehingga model tersebut bebas dari gejala heteroskedastisitas. 
Tabel 15.

Hasil Uji Multikolinieritas

\begin{tabular}{|c|c|c|}
\hline Variabel & Tolerance & VIF \\
\hline Keterlibatan Kerja $\left(\mathrm{X}_{1}\right)$ & 0,651 & $\overline{1,536}$ \\
\hline Iklim Organisasi $\left(\mathrm{X}_{2}\right)$ & 0,976 & 1,024 \\
\hline Kepuasan Kerja $\left(\mathrm{X}_{3}\right)$ & 0,639 & 1,564 \\
\hline
\end{tabular}

Sumber: Data diolah, 2018

Tabel 15. menunjukkan bahwa nilai tolerance dan VIF dari variabel keterlibatan kerja, iklim organisasi dan kepuasan kerja. Nilai tersebut menunjukkan bahwa nilai tolerance untuk setiap variabel lebih besar dari 0,10 (10\%) dan nilai VIF lebih kecil dari 10 yang berarti model persamaan regresi bebas dari multikolinieritas.

\section{Uji Kelayakan Model (Uji F)}

Tabel 16.

Hasil Uji F

\begin{tabular}{cccccc}
\hline Model & $\begin{array}{c}\text { Sum of } \\
\text { Squares }\end{array}$ & df & Mean Square & F & Sig. \\
\hline Regression & 295,601 & 3 & 98,534 & 13,409 & 0,000 \\
Residual & 614,977 & 41 & 14,999 & & \\
\hline Total & 910,578 & 44 & & & \\
\hline
\end{tabular}

Sumber: Data diolah, 2018

Tabel 16 menunjukkan nilai signifikan sebesar 0,000 yang lebih kecil dari nilai $\alpha=0,05$ maka model regresi linier berganda layak digunakan sebagai alat analisis.

Nilai Koefisien Determinasi $\left(\mathbf{R}^{2}\right)$

Tabel 17.

Hasil Uji Koefisien Determinasi $\left(\mathbf{R}^{2}\right)$

\begin{tabular}{cccc}
\hline $\mathbf{R}$ & R Square & Adjusted $R$ Square & $\begin{array}{c}\text { Std Error of the } \\
\text { Estimate }\end{array}$ \\
\hline 0,501 & 0,362 & 0,335 & 2,765 \\
\hline
\end{tabular}

Sumber: Data diolah, 2018 
Tabel 17. menunjukkan nilai $R$ Square adalah 0,362 yang artinya 36,2 persen komitmen organisasional karyawan di Restoran Ingka dipengaruhi oleh keterlibatan kerja, iklim organisasi dan kepuasan kerja yang diterapkan di perusahaan, sedangkan sisanya 63,8 persen dijelaskan oleh faktor lain yang tidak dijelaskan dalam penelitian ini.

\section{Uji Parsial (Uji t)}

Hasil dari uji parsial (Uji t) dapat dilihat pada tabel 12. dapat dijelaskan masing-masing variabel independen terhadap variabel dependen sebagai berikut: Hipotesis pertama, berdasarkan hasil analisis pengaruh keterlibatan kerja terhadap komitmen organisasional diperoleh nilai Sig. t sebesar 0,010. Nilai Sig. t 0,010< 0,05 mengindikasikan bahwa $\mathrm{H}_{0}$ ditolak dan $\mathrm{H}_{1}$ diterima. Hasil ini mempunyai arti bahwa keterlibatan kerja berpengaruh positif dan signifikan terhadap komitmen organisasional karyawan yang berarti apabila keterlibatan kerja semakin baik maka komitmen organisasional karyawan di Restoran Ingka akan meningkat dan sebaliknya, semakin buruk keterlibatan kerja maka komitmen organisasional yang dimiliki karyawan di Restoran Ingka akan menurun. Hasil penelitian ini sesuai dengan penelitian sebelumnya yang dilakukan oleh Mariyanti (2014) menyatakan bahwa salah satu factor yang memengaruhi komitmen organisasional adalah keterlibatan kerja. Sehingga kenaikan keterlibatan kerja maka akan meningkatkan komitmen organisasional. Chin (2012) menyatakan bahwa adanya kontribusi secara signifikan antara keterlibatan kerja terhadap komitmen organisasional. Hal serupa juga disebutkan pada penelitian yang dilakukan oleh Ansel dan Wijono (2012), Logahan (2014), serta Liwun dan 
I Gde Raka Ariana, Pengaruh Keterlibatan Kerja...

Prabowo (2015) menyatakan bahwa keterlibatan kerja berpengaruh positif terhadap komitmen organisasional.

Hipotesis kedua, berdasarkan hasil analisis pengaruh iklim organisasi terhadap komitmen organisasional diperoleh nilai Sig. $\mathrm{t}$ sebesar 0,032. Nilai Sig. $\mathrm{t}$ $0,032<0,05$ sehingga $\mathrm{H}_{0}$ ditolak dan $\mathrm{H}_{1}$ diterima. Hasil ini mempunyai arti bahwa iklim organisasi berpengaruh positif dan signifikan terhadap komitmen organisasional karyawan yang berarti apabila iklim organisasi semakin baik maka komitmen organisasional karyawan di Restoran Ingka akan meningkat dan sebaliknya, semakin buruk iklim organisasi maka komitmen organisasional yang dimiliki karyawan di Restoran Ingka akan menurun. Hasil penelitian ini sesuai dengan penelitian Wirawan (2009) menyatakan bahwa iklim organisasi berkaitan dengan penciptaan lingkungan kerja yang kondusif yang akan menciptakan hubungan kerjasama yang harmonis antar elemen organisasi. Semakin tinggi iklim organisasi dalam perusahaan, maka akan semakin tinggi komitmen karyawan. Affandi (2002), Safiri dan Putra (2015), Adiapsari (2012), Suarningsih dkk. (2013), serta Widiarti dan Dewi (2016) juga menyatakan bahwa iklim organisasi berpengaruh positif terhadap komitmen organisasional.

Hipotesis ketiga, berdasarkan hasil analisis pengaruh kepuasan kerja terhadap komitmen organisasional diperoleh nilai Sig. $t$ sebesar 0,007. Nilai Sig. $t$ $0,007<0,05$ sehingga $\mathrm{H}_{0}$ ditolak dan $\mathrm{H}_{1}$ diterima. Hasil ini mempunyai arti bahwa kepuasan kerja berpengaruh positif dan signifikan terhadap komitmen organisasional karyawan yang berarti apabila kepuasan kerja semakin baik maka komitmen organisasional karyawan di Restoran Ingka akan meningkat dan 
sebaliknya, semakin buruk kepuasan kerja maka komitmen organisasional yang dimiliki karyawan di Restoran Ingka akan menurun. Hasil penelitian ini sesuai dengan penelitian Jonathan et al. (2013) yang menyatakan bahwa terdapat pengaruh positif kepuasan kerja terhadap komitmen organisasional, sehingga apabila karyawan puas terhadapan pekerjaannya maka karyawan akan semakin berkomitmen terhadap organisasi. Oyewobi et al. (2012) pada penelitiannya quantity surveyor dalam pelayanan publik Nigeria menyatakan bahwa memang terdapat korelasi positif antara variabel kepuasan kerja dengan komitmen kerja. Hasil penelitian dari Sutanto dan Tania (2013), Srivastava (2013), serta Devi dan Adnyani (2015) menyatakan bahwa kepuasan kerja berpengaruh positif dan signifikan terhadap komitmen organisasional.

\section{SIMPULAN DAN SARAN}

Simpulan dari penelitian ini berdasarkan hasil analisis dan pembahasan adalah sebagai berikut: (1) Keterlibatan kerja berpengaruh positif dan signifikan terhadap komitmen organisasional karyawan di Restoran Ingka. Hal ini menunjukkan semakin baik keterlibatan kerja maka komitmen organisasional juga akan meningkat. (2) Iklim organisasi berpengaruh positif dan signifikan terhadap komitmen organisasional karyawan di Restoran Ingka. Hal ini menunjukkan semakin baik iklim organisasi maka komitmen organisasional juga akan meningkat. (3) Kepuasan kerja berpengaruh positif dan signifikan terhadap komitmen organisasional karyawan di Restoran Ingka. Hal ini menunjukkan 
I Gde Raka Ariana, Pengaruh Keterlibatan Kerja...

semakin tinggi tingkat kepuasan kerja yang dirasakan oleh karyawan di tempat kerja maka komitmen organisasional juga akan meningkat.

Saran yang dapat diberikan berdasarkan hasil analisis dan pembahasan adalah sebagai berikut: (1) Manajemen Restoran Ingka diharapkan dapat memperhatikan hubungan personel, yaitu keeratan hubungan kerja antara manajemen dengan karyawan. Manajemen dapat menjaga komunikasi dan lebih sering mengadakan kegiatan bersama para karyawan seperti games, outbond, temu keluarga karyawan yang nantinya akan membuat para karyawan akan semakin akrab dengan pimpinan dan juga semakin akrab dengan sesama rekan kerja. (2) Manajemen Restoran Ingka hendaknya memperhatikan kepuasan kerja dari karyawannya karena bukan tidak mungkin dengan faktor tersebut dapat memberikan hal lebih kedepannya. Manajemen Restoran Ingka dapat meningkatkan pengawasan menyeluruh terhadap pekerjaan karyawan, memberikan upah sesuai dengan beban kerja, memberikan kesempatan untuk mendapatkan promosi jabatan dan memastikan hubungan antar rekan kerja terjalin baik sehingga dengan hal tersebut karyawan akan merasa puas berada di perusahaan. Restoran Ingka yang bergerak dibidang pelayanan jasa harus memiliki karyawan yang mempunyai komitmen kuat sehingga dapat memberikan pelayanan yang baik dan dapat memajukan perusahaan. (3) Peneliti selanjutnya yang melakukan penelitian serupa dapat mempeluas cakupan lokasi serta mempertimbangkan variabel-variabel lain yang dapat mempengaruhi komitmen organisasional. 


\section{REFRENSI}

Affandi, H. 2002. Pengaruh Iklim Organisasi Terhadap Kepuasan Kerja, Komitmen dan Kinerja Pegawai (Studi Kasus Pada Pegawai di Lingkungan Pemerintah Kota Semarang) Masters Thesis Pascasarjana Universitas Diponegoro.

Amin, A., Yusnita, Y., Ibrahim, M., Y., and Muda, S. 2013. Transformational leadership and life satisfaction among homestay participans pro-gram: The mediating effect of attitude. International Journal of Business and Social Science, 4 (3) : 235-243.

Ansel, Maria Finesesia dan Sutarto Wijono. 2012. Pengaruh Keterlibatan Kerja dan Kepuasan Kerja Terhadap Komitmen Organisasi Polisi di Kepolisian Resor (POLRES) Ende. Journal of Applied Sciences, 5 (2) :125-142.

Ardana, I Komang., Mujiati, Ni Wayan., dan Utama, I Wayan Mudiartha. 2012. Manajemen Sumber Daya Manusia. Edisi Pertama. Yogyakarta: Graha Ilmu.

Aziri, B. 2011. Job Satisfaction: A Literature Review. Management Research and Practice, 3(4) : 77-86.

Chin, Oldenburg, Day and Sun. 2012. Work Values, Job Involvement, and Organizational Commitment in Taiwanese Nurses. International Journal of Psychology and Behavioral Sciences. Vol. 2, Np. 3 : 64-70.

Crow, M S. \& Lee, Chang-Bae \& Joo, Jae-Jin, 2012. Organizational Justice and Organizational Commitment Among South Korean Police Officers: An Investigation Of Job Satisfaction. International Journal of Police Strategies \& Management, 35 (2) : 402-423.

Devi, D. A. W dan I Gusti Ayu Dewi Adnyani. 2015. Pengaruh Kepuasan Kerja Karyawan Terhadap Komitmen Organisasional dan Organization Citizenship Behavior (OCB) pada PT Maharani Primasakti Denpasar. EJurnal Manajemen Unud, 4 (12) : 4105-4134.

Fatt, C. K., Khin, Edward. W., and Heng, T. N. 2010. The Impact of Organizational Justice on Employee's Job Satisfaction: The Malaysian Companies Perspectives. American Journal of Economics and Business Administration, 12(2) : 56-63.

Handoko, T. Hani. 2014. Manajemen Personalia dan Sumber Daya Manusia. Edisi Kedua. Yogyakarta: BPFE. 
Indrawan, Dewa Cahyadi dan A.A. Sagung Kartika Dewi. 2014. Pengaruh Kompensasi, Kepemimpinan, dan Lingkungan Kerja Fisik Terhadap Kepuasan Kerja Karyawan PT. Cargo Asas International, Denpasar. EJurnal Manajemen Unud, 3 (6) : 1767-1779.

Jonathan, Henry, Casius Darroux and Jared Massele. 2013. Perceived Job Satisfaction and its impact on Organizational Commitment An empirical study of public secondary school teachers in Dodoma, Tanzania, OSR Journal of Business and Management (IOSR-JBM), 13 (3) : 41-52.

Karim, Faisal dan Omar Rehman. 2012. Impact of Job Satisfaction, Perceived Organizational Justice and Employee Empowerment on Organizational Commitment in Semi-Government Organizations of Pakistan. Journal of Business Studies Quarterly. 3(4) : 92-104.

Kusumaningtyas, Amiartuti. 2013. Pengaruh Iklim Organisasi dan Kepemimpinan Terhadap Kepuasan Kerja Karyawan PT. Persada Jaya Indonesia di Kabupaten Sidoarjo. Jurnal Mitra Ekonomi dan Manajemen Bisnis, 4 (1) : 107-120.

Logahan, dan Aesaria. 2014. Budaya Organisasi dan Keterlibatan Kerja Terhadap Komitmen Organisasi Berdampak Pada Kinerja Karyawan Pada Btn Ciputat. Binus Busines Review.Vol. 5, No. 2 : 551-563.

Luthans, Freed. 2006. Perilaku Organisasi, (Alih Bahasa V.A Yuwono, dkk). Edisi Bahasa Indonesia. Yogyakarta: ANDI.

Mariyanti, Eka. 2014. Pengaruh Keterlibatan Kerja dan Kepuasan Kerja terhadap Komitmen Organisasi (Studi Kasus Pada Perawat Rumah Sakit Swasta Di Kota Padang). Jurnal KomTekInfo Fakultas Ilmu Komputer. 1 (1) : 38-45.

Mehdi, Rezvaniamin., Zahra, Pournamdar., and Mahshid, Nazemzadeshoaei. 2013. Job satisfaction and organizational commitment among nurses. Life Science Journal, 10(5) : 1-5.

Mohammed, Sheik, dan Anisa. 2012. Relationship Between Organizational Commitment and Organizational Citizenship Behavior. The IUP Journal of Organizational Behavior, 9 (3) : 122-143.

Oyewobi, Luqman Oyekumele; Bolaji Suleiman \& Abubakar Mhamad-Jamil. 2012. Job Satisfaction and Job Commitment: A Study of Quantity Surveyors in Nigerian Public Service. International Journal of Business and Management, 7 (5) : 179:191. 
Rahati, Sotudeh-Arani, Adib-Hajbaghery, and Masjid Rostami. 2015. Job Involvement and Organizational Commitment of Employees of Prehosoital Emergency Medical System. Nurs Midwifery Swd, Vol. 4, No. 4 : 1-6.

Rivai Veithzal dan Deddy Mulyadi. 2012. Kepemimpinan dan Perilaku Organisasi Edisi Ketiga. Jakarta: PT. Rajagrafindo Persada.

Safitri, I.P, Wahyu. Rahardjo, dan Kusdi. Djudi, Moch. 2014. Analisis Perbedaan Komitmen Organisasi Berdasarkan Status Karyawan (Studi Pada Karyawan PT. Kobexindo Tractors Tbk. Representative Office Bengkulu). Jurnal Administrasi Bisnis, 10(1) : 215-239.

Safiri, Amiri, dan T. Rolli Ilhamsyah Putra. 2015. Pengaruh Kepuasan Kerja dan Iklim Organisasi Terhadap Komitmen Pegawai dan Dampaknya pada Kinerja Pegawai Dinas Pendapatan dan Kekayaan Aceh. Jurnal Manajemen Pascasarjana Universitas Syiah Kuala, 4 (3) : 82-91.

Srivastava, Shalini. 2013. Job Satisfaction and Organizational Commitment Relationship: Effect of Personality Variabels. Vision: The Journal of Business Perspective, 17 (2) : 159-167.

Sugiyono. 2014. Metode Penelitian Bisnis. Cetakan Kesebelas. Bandung: C.V Alfabeta.

Suma, Saimir, dan Jonida Lesha. 2013. Job Satisfaction and Organizational Commitment: The Case of Shkorda Municipality. European Scientific Journal, 9(17) : 41-51.

Suryanatha, A.A. Ngr.Bayu. 2014. Pengaruh Kepemimpinan Transformational dan Komitmen Organisasi Terhadap Kepuasan Kerja Karyawan Dan Organizational Citizenship Behavior (ocb) Pada Baleka Resort Hotel \& Spa Legian. Jurnal Manajemen Udayana. 2(9) : 2579-2614.

Susanty, Etty. 2012. Pengaruh Iklim Organisasi terhadap Kepuasan Kerja dan Komitmen Pegawai pada Universitas Terbuka. Jurnal Organisasi dan Manajemen, 8 (2) : 121-134.

Sutanto, Eddy M. dan Anastasia Tania. 2013. Pengaruh Motivasi Kerja dan Kepuasan Kerja terhadap Komitmen Organisasional Karyawan PT. DAI KNIFE di Surabaya. Jurnal Manajemen Universitas Kristen Petra. 1 (3) : 120.

Suwanto, dan Priansa, D.J. 2011. Manajemen SDM dalam Organisasi Publik dan Bisnis. Bandung: Alfabeta.

Wirawan. 2009. Budaya dan Iklim Organisasi. Jakarta: Salemba Empat. 
I Gde Raka Ariana, Pengaruh Keterlibatan Kerja...

Widiarti N.L.D. dan A.A. Sagung Kartika Dewi. 2016. Pengaruh Iklim Organisasi dan Kepuasan Kerja Terhadap Komitmen Organisasional Pada Dinas Pendapatan Provinsi Bali. E-Jurnal Manajemen Unud, 5 (10) : 6345-6372.

NB:

- PAGE PAPER A4

- HEADER FORMAT LIHAT PEDOMAN PENULISAN PADA WEB ojs.unud.ac.id E- Jurnal Manajemen (FONT TNR 11pt)

- HALAMAN FORMAT TNR 11pt PADA OJOK KANAN BAWAH

- JUMLAH HALAMAN 25-30 DILUAR REFERENSI 